УДК 633.72:631.8:577.1:581.1

DOI 10.30679/2219-5335-2019-6-60-114-123

ВЛИЯНИЕ БИОГЕННЫХ ЭЛЕМЕНТОВ (Ca, Mg)

НА АКТИВНОСТЬ КАТАЛАЗЫ

В МОЛОДЫХ ПОБЕГАХ

И ЛИСТЬЯХ ЧАЯ

(CAMELLIA SINENSIS (L.) KUNTZE)

Малюкова Людмила Степановна

д-р биол. наук, профессор РАН

главный научный сотрудник

лаборатории агрохимии

и почвоведения

e-mail: Malukovals@mail.ru

Притула Зоя Васильевна

канд. с.-х. наук

ведущий научный сотрудник

лаборатории физиологии

и биохимии растений

e-mail: PritulaZV@mail.ru

Федеральное государственное

бюджетное научное учреждение

«Всероссийский научно-

исследовательский институт

ияветоводства и субтропических

культур», Сочи, Россия

Для оценки выносливости растений в условиях окислительного стресса применяют широкий набор показателей, характеризующих функционального состояния растений. В качестве одного из наиболее информативных показателей, наряду с другими ферментами

(пероксидаза, супероксиддисмутаза и др.), рассматривается каталаза.

Целью данной работы было изучить влияние корневого внесения кальций и магнийсодержащих веществ на активность каталазы в листьях чайного растения. Во влажно-субтропической зоне России на чайных плантациях в условиях полевого опыта с удобрениями изучена активность антиоксидантного фермента каталазы в молодых побегах и зрелых листьях чая

UDC 633.72:631.8:577.1:581.1

DOI 10.30679/2219-5335-2019-6-60-114-123

\section{INFLUENCE OF BIOGENIC ELEMENTS (Ca, Mg) \\ THE CATALASE ACTIVITY IN THE YOUNG SHOOTS AND LEAVES OF TEA PLANT (CAMELLIA SINENSIS (L.) KUNTZE)}

Malyukova Lyudmila Stepanovna

Dr. Sci. Biol., Professor of RAS

Chief Research Associate

of Agrochemistry

and Soil Science Laboratory

e-mail: Malukovals@mail.ru

Pritula Zoya Vasilevna

Cand. Agr. Sci.

Leading Research Associate

of Plant Physiology

and Biochemistry Laboratory

e-mail:PritulaZV@mail.ru

Federal State Budgetary

Scientific Institution

«Russian Research Institute

of Floriculture

and Subtropical Crops»,

Sochi, Russia

To assess the endurance of plants to oxidative stress, a wide range of indicators characterized the functional state of plants is used. As one of the most informative indicators, along with other enzymes (peroxidase, superoxide dismutase, etc.), catalase is considered. The aim of this work was to study the effect of root application of calcium and magnesium-containing substances on the activity of catalase in the leaves of a tea plant. In the humid subtropical zone of Russia on tea plantations under the conditions of a field experiment with fertilizers, the activity of the antioxidant enzyme catalase in young shoots and mature leaves of Kolhida tea was studied. The dynamics 
сорта Колхида. Показана динамика концентрации клеточного сока молодых побегов и каталазной активности листьев чайного растения в различные периоды вегетации, в том числе охватывающие засуху в сочетании с непродолжительной гипертермией, обусловленной суточной динамикой. Установлено, что повышение концентрации клеточного сока молодых побегов в стрессовых условиях сопровождалось увеличением активности каталазы зрелого листа $(\mathrm{r}=0,60)$ и ингибированием активности каталазы молодых побегов (r=-0,59). Изучено влияние корневого применения кальция в виде природного вещества (100 кг/га $\mathrm{CaO})$ и магния в форме $\mathrm{MgSO}_{4}(60$ кг/га $\mathrm{Mg}$ ) на активность антиоксидантного фермента каталазы в молодых побегах и зрелых листьях чая. Показано (в сравнении с контролем) увеличение активности каталазы в зрелых листьях в отдельные периоды на фоне применения кальцийсодержащего природного материала. Применение магнийсодержащих удобрений снижало устойчивость растений к стрессу, что фиксировалось по существенному увеличению концентрации клеточного сока в молодых побегах и более низкой активности каталазы в молодых и зрелых листьях.

Ключевые слова: ЧАЙНОЕ РАСТЕНИЕ, КАЛЬЦИЙ, МАГНИЙ, АКТИВНОСТЬ КАТАЛАЗЫ ЛИСТЬЕВ, ВЛАЖНЫЕ СУБТРОПИКИ of the concentration of cell sap of young shoots and the catalase activity of tea plant leaves during different periods of vegetation, including those covering drought in combination with short-term hyperthermia due to day dynamics, is shown. It was found that an increase in the concentration of cell sap of young shoots under stressful conditions was accompanied by an increase in the activity of mature leaf catalase $(r=0.60)$ and inhibition of catalase activity in young shoots $(r=-0.59)$. The effect of the root use of calcium in the form of a natural substance $(100 \mathrm{~kg} / \mathrm{ha} \mathrm{CaO})$ and magnesium in the form of $\mathrm{MgSO}_{4}$ $(60 \mathrm{~kg} / \mathrm{ha} \mathrm{Mg})$ on the activity of the antioxidant enzyme catalase in young shoots and mature tea leaves was studied. It is shown (in comparison with the control) an increase in the activity of catalase in mature leaves in certain periods against the background of the use of calcium-containing natural material. The use of magnesiumcontaining fertilizers reduced the resistance of plants to stress, which was recorded by a significant increase in the concentration of cell sap in young shoots and lower catalase activity in young and mature leaves.

Key words: TEA PLANT, CALCIUM, MAGNESIUM, CATALASE LEAVES ACTIVITY, WET SUBTROPICS

Введение. Длительные периоды недостаточной водообеспеченности летом, характерные для влажно-субтропической зоны России, являются наиболее губительным фактором для растений, поскольку приводят к окислительному стрессу с образованием активных форм кислорода (АФК) и существенной потере урожая плодовых культур и чая, которая может быть более 50 \% [1-3]. Возделывание чая, в связи с его биологическими особенностями (ацидофильная культура), приурочено к кислым 
Плодоводство и виноградарство Юга России № 60(06), 2019 г.

и сильнокислым почвам с высоким содержанием подвижного алюминия и низкой степенью насыщенности основаниями (в частности Са и $\mathrm{Mg}$ ) по всему профилю [4].

При длительной эксплуатации многолетних насаждений возникающий дефицит этих элементов (в условиях прогрессирующей ацидизации почв) может отрицательно сказаться на продуктивности плантаций, качестве сырья и адаптивности растений. Так известно, что кальций рассматривается как один из наиболее эффективных индукторов стрессоустойчивости растений, осуществляющих сигнальную функцию в усилении синтеза стрессорных белков и других защитных соединений, обеспечивающих устойчивость растений к неблагоприятным факторам среды, а также последующий их выход из этого состояния [5-7]. Магний является структурным элементом пигмента хлорофилла, осуществляющего фотосинтетическую деятельность растений. Учитывая важную роль этих элементов в функциональном состоянии растений, актуальность изучения эффективности применения их на чайных плантациях очевидна $[8,9]$.

Для оценки выносливости растений к окислительному стрессу применяют широкий набор показателей функционального состояния растений: антиоксидантные ферменты, фотосинтетические пигменты, стрессорные белки $[8,10,11]$. Одним из наиболее информативных показателей, наряду с другими ферментами (пероксидаза, супероксиддисмутаза и др.), рассматривается каталаза - основной фермент, ликвидирующий избыточные количества пероксида водорода, относящегося к индукторам АФК $[6,12]$. Исследуется влияние различных абиотических факторов на каталазную активность многих культур [13-16], в том числе и чая, для которого этот фермент рассматривается как критерий оценки его устойчивости к стрессам [17].

Целью данной работы было изучить влияние корневого внесения кальций и магнийсодержащих веществ на активность каталазы в листьях чайного растения. 
Плодоводство и виноградарство Юга России № 60(06), 2019 г.

Объекты и методы исследований. Исследования проводили на базе полевого опыта с удобрениями (корневое внесение мезо- и микроудобрений) на плантации чая сорта Колхида (1983 года посадки), п. Дагомыс. Опыт с удобрениями заложен в 2003 году. Сравнивали 3 варианта: контроль (фон) - N240P70K90; 2) сернокислый магний - Mg 60; 3) кальцийсодержащий материал-100 $\mathrm{CaO}$, который является природным удобрением глинисто-известковые отходы Каменского карьера (Адлерский район), образующиеся при дроблении известняков на мелкие фракции щебня. Содержание $\mathrm{CaCO}_{3}$ составляет 70-75\%.

Вещества вносили в поверхностный слой почвы на фоне макроудобрений в дозе N240P70К90. Основные дозы веществ вносились в весенний период. В конце июня осуществляли подкормку азотными удобрениями.

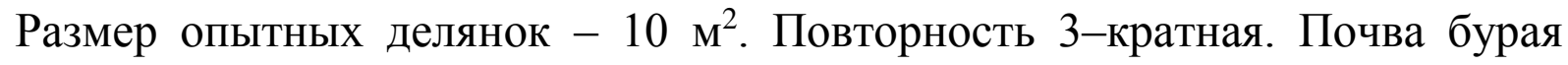
лесная кислая малогумусная глинистая мощная на элюво-делювии аргиллитов. Исследования провели в 2014-2015 гг. Для изучения динамики активности каталазы проведены отборы полностью вызревших листьев чая в июле и августе (3-4 месячный возраст), в периоды наиболее высокой напряжённости по влагообеспеченности растений.

Трехлистную флешь для определения каталазы и ККС отбирали в динамике за период май-август. В 3-листной флеши определяли концентрацию клеточного сока (ККС) рефрактометрически по Л.А. Филиппову [18], которая является показателем влагообеспеченности растений. Определение активности каталазы в листьях проводили газометрическим методом по методике И.И. Гунара [19]. Навеску 250 мг свежих листьев растирали в ступке с $\mathrm{CaCO}_{3}$ и добавляли 20 мл воды, затем приливали 5 мл $3 \%$ $\mathrm{H}_{2} \mathrm{O}_{2}$ и по изменению уровня воды в бюретке фиксировали количество выделившегося кислорода за 3 минуты. Обработка экспериментального материала проведена методами вариационно-описательной статистики. 
Обсуждение результатов. Анализ гидротермических факторов показал, что в 2014 году наиболее засушливым был август в связи с дефицитом осадков (13 мм за месяц) и высокой среднесуточной температурой воздуха $\left(25,4{ }^{\circ} \mathrm{C}\right)$ с максимумом до $33{ }^{\circ} \mathrm{C}$. В этих условиях концентрация клеточного сока 3-листной флеши была на границе «норма-начало нарушения водного режима" и составляла 8,1-8,6 \% (рис. 1).

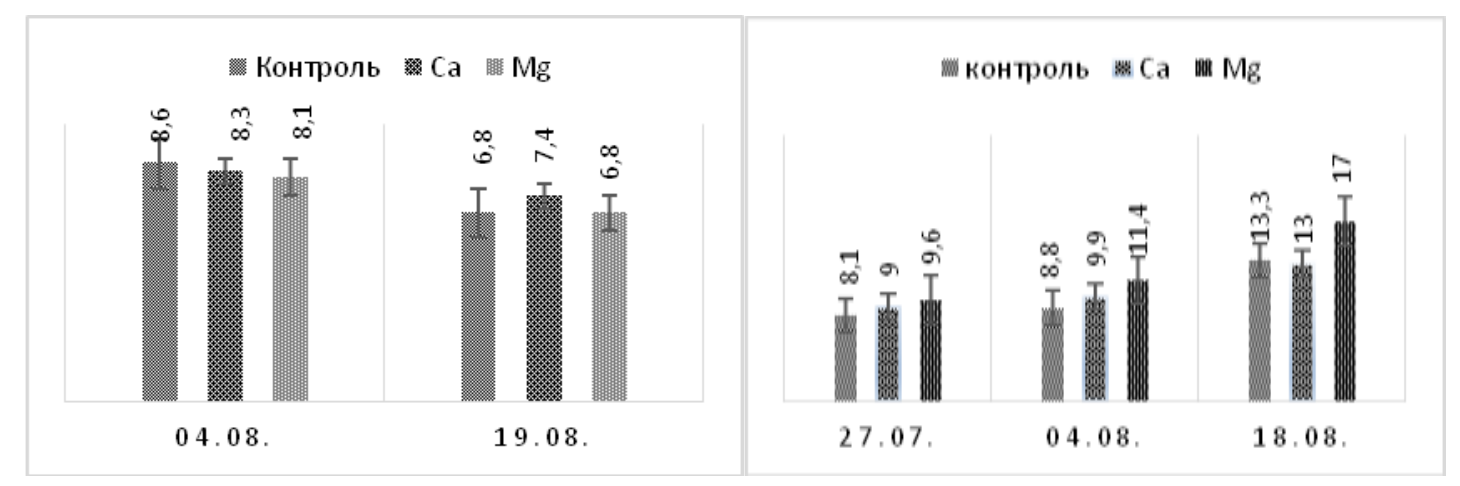

Рис. 1. Концентрация клеточного сока (\%) в 3-листной флеши чайного растения, 2014-2015 гг.

В 2015 году в летний период сформировались экстремальные условия: среднесуточная температура в мае-августе составляла $21,3-25,7{ }^{\circ} \mathrm{C}$ и выпало 434 мм осадков, август-сентябрь характеризовались дефицитом осадков (менее 30 мм за 2 месяца) и высокой среднесуточной температурой воздуха $\left(+24,2-25,7^{\circ} \mathrm{C}\right)$ с максимумом до $+32{ }^{\circ} \mathrm{C}$. В июле отмечался рост ККС до значений 9-11 \%, к средине августа ККС достигла уже 13-17 \%, которая к 1-й декаде сентября возросла до 14-19 \%, что привело к завяданию флешей на отдельных вариантах.

Активность антиоксидантного фермента каталазы в зрелых листьях чайного растения в эти периоды находилась в достаточно высоких пределах (рис. 2), что являлось типичным ответом растений на возникновение окислительного стресса. При этом ККС в 3-листных флешах, отражающая уровень водообеспеченности растений, имела прямую корреляцию с активностью каталазы в зрелых листьях $(\mathrm{r}=0,60)$. 


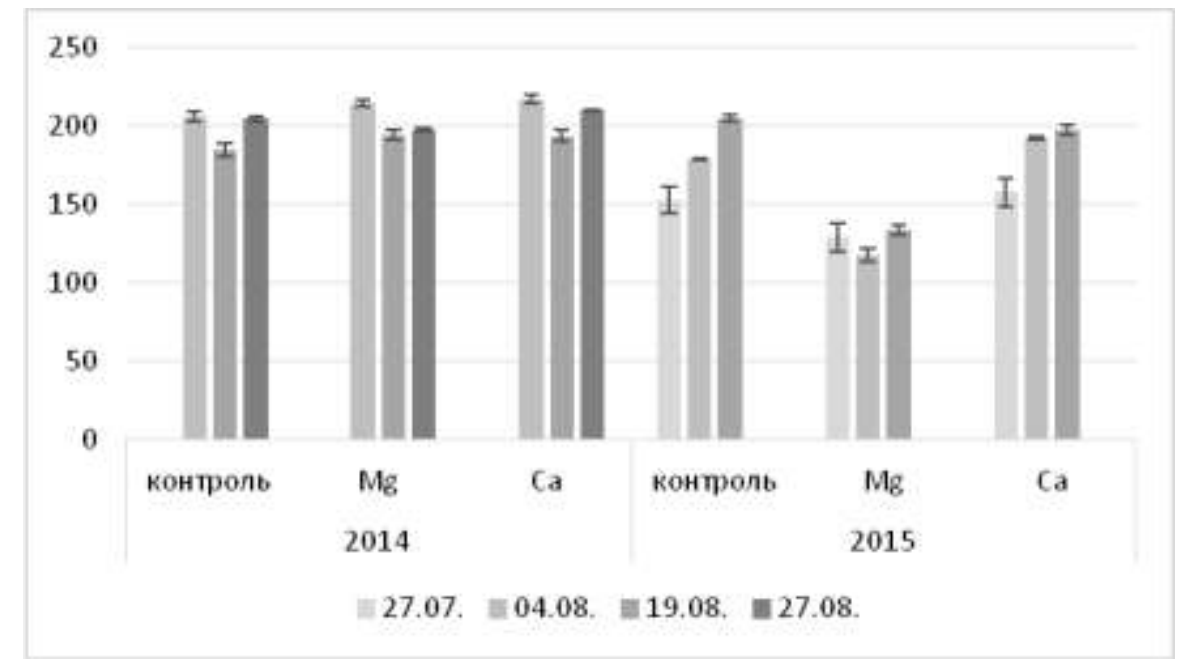

Рис. 2. Каталазная активность (мл $\mathrm{O}_{2} / \Gamma$ за 3 мин.) в зрелых листьях чайного растения в напряжённый по влагообеспеченности период

В 2014 году (на границе норма-начало нарушения водного режима) активность каталазы в вариантах с кальцием и магнием достоверно превышала контроль, что рассматривалось как более раннее распознавание стресса. В исследованиях с применением экзогенного кальция предполагается, что при стрессе кальциевый сигнал передаётся по пути, компонентами которого являются активные формы кислорода, что влияет на процессы, регулирующие ферменты антиоксидантной защиты [20-22].

При сильно выраженном стрессе (критические значения ККС, 2015 г.) активность каталазы в варианте с магнием значительно снижалась относительно контроля и варианта с кальцием, что отражалось на устойчивости растений. В этих условиях активность каталазы в листьях в случае внесения кальция была выше или соизмерима с контролем (см. рис. 2).

3-листная флешь (молодой побег) чайного растения характеризовалась значительно меньшей каталазной активностью по сравнению со зрелыми листьями (рис. 3), что, по мнению многих исследователей, обусловлено рядом причин: повышенная освещенность и, соответственно, фотостресс, более высокая степень обезвоживания по сравнению с другими листьями, возраст листа. 

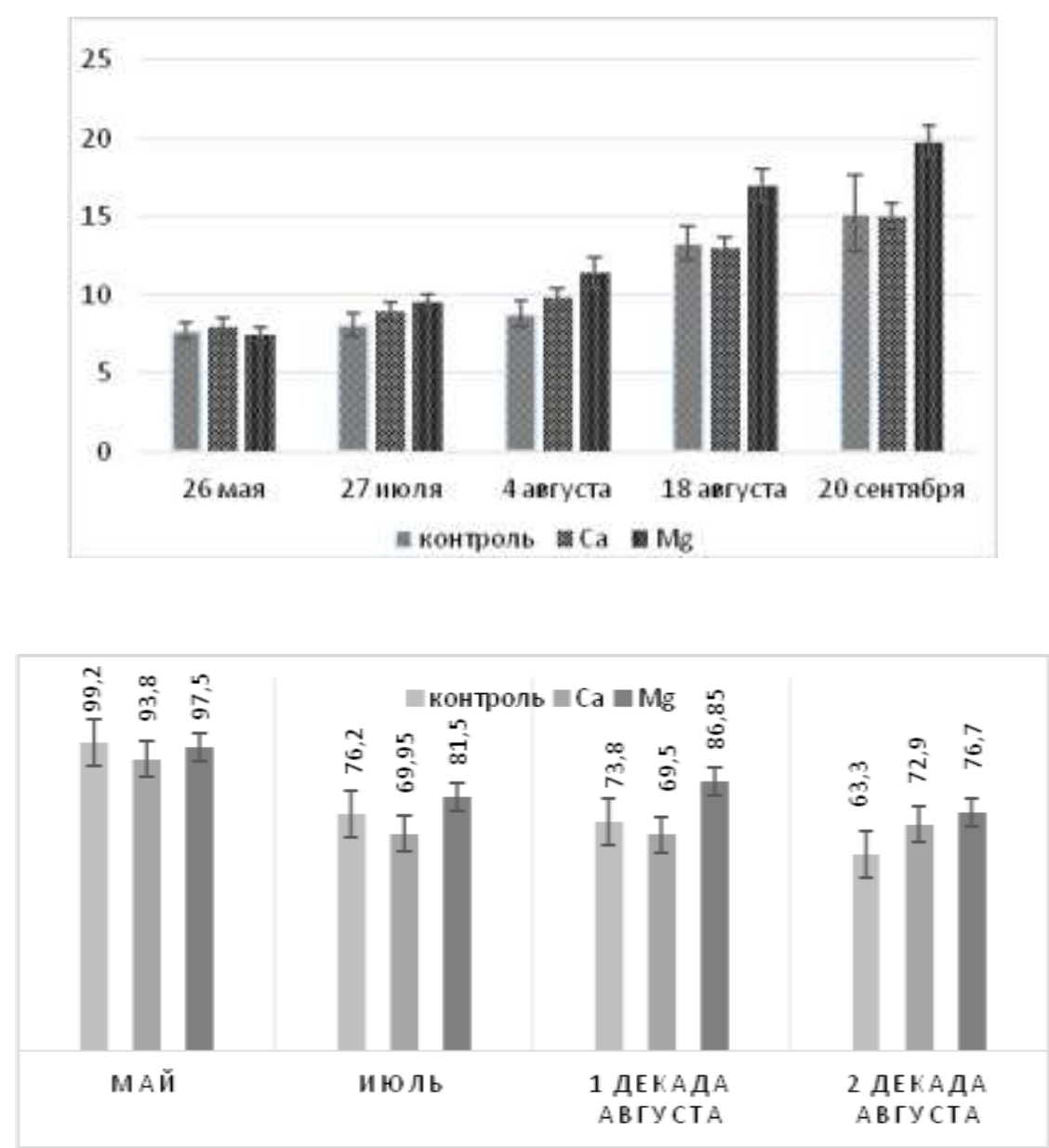

Рис. 3. Динамика ККС (\%) и активности каталазы (мл $\mathrm{O}_{2} / \Gamma$ за 3 мин.) в 3-листных флешах чайного растения

В динамике вегетационного периода установлено увеличение ККС и снижение активности фермента в 3-листной флеши с мая (оптимальные по влагообеспеченности условия) к августу (нарушение водного режима) $(\mathrm{r}=-0,59)$. В оптимальных условиях, а также в начале стрессового периода, ККС и активность каталазы в целом были соизмеримы по вариантам опыта. Однако по мере усиления засухи (август-сентябрь) на варианте с магнием для 3-листной флеши отмечен рост ККС до критических значений, что привело к морфологическим изменениям мезоструктуры растений, которые визуально проявились в необратимом завядании молодых побегов. На контроле и варианте с кальцием усиление стресса также приводило к росту ККС и ингибированию активности каталазы, но менее выраженному. 
Плодоводство и виноградарство Юга России № 60(06), 2019 г.

Bыводы. Таким образом, установлено, что повышение концентрации клеточного сока (стрессовые условия) сопровождалось увеличением активности каталазы зрелого листа растений чая $(\mathrm{r}=0,60)$ и ингибированием активности каталазы молодых побегов (r=-0,59).

Показано, что на фоне корневого применения кальцийсодержащего природного материала растения в определённые периоды характеризовались более высокой активностью каталазы, участвующей в повышении устойчивости к засухе. Применение магнийсодержащих удобрений снижало устойчивость растений к стрессу, что фиксировалось по росту ККС и более низкой активности каталазы в зрелых листьях чая.

\section{Литература}

1. Bhagat R.M., Baruah R.D., Cacigue S. Climate and tea [Camellia sinensis (L.) O. Kuntze] production with special reference to northeastern India: a review // Journal of Environmental Research and Development. 2010. №4 (4). P. 1017-1028.

2. Baruah R.D., Bhagat R.M. Climate trends of Northeastern India: a longterm pragmatic analysis for tea production // Two and a Bud. 2012. № 59(2). P. 46-49.

3. Малюкова Л.С. Оценка влияния метеорологических условий на биопродуктивность почв чайных плантаций в условиях Черноморского побережья России // Плодоводство и ягодоводство России. 2014. №38 (1). С. 255-261.

4. Малюкова Л.С., Козлова Н.В. Зональные типы почв влажных субтропиков Черноморского побережья России. // Субтропическое и декоративное садоводство: науч. тр. / ГНУ ВНИИЦ и СК Россельхозакадемии. Вып. 56. Сочи, 2016. С. 146-156.

5. Bush D.S. Calcium regulation in plant cells and its role in signaling. Annu. Rev. Plant Physiol. Plant Mol. Biol // 1995. № 46. P. 95-122.

6. Bowler C., Fluhr B. The role of calcium and activated oxygen as signals for controlling cross-tolerance. Trend plant sci. // 2000.№ 5. P.241-243.

7. Yin D., Kuczera K., Squer T.C. The sensitivity of carboxyl-terminal methionines in calmodulin isoforms to oxidation by $\mathrm{H} 2 \mathrm{O} 2$ modulates the ability to activate the plasma membrane Ca- ATPase. Chem. Res.toxicol. // 2000.v.13. p. 103-110.

8. Upadhyaya H, Dutta B.K., Sahoo L., Panda S.K. Comparative effect of Ca, K, Mn and B on post-drought stress recovery in tea [Camellia sinensis (L.) O. Kuntze] // Аmerican Journal Plant Science. 2012. №3. P. 443-460.

9. Притула 3.В., Малюкова Л.С. Влияние биогенных элементов (Mg, $\mathrm{Zn}, \mathrm{B})$ на водный режим чая (Camellia Sinensis (L.) Kuntze) в условиях продолжительной засухи и гипертермии // Проблемы агрохимии и экологии. 2017. № 3. C. 31-34.

10. Maritim T.K., Kamunya S.M., Mireji P., Wendia C.M., Muoki R.C., Cheruiyot E.K., Wachira F.N. Physiological and biochemical response of tea (Camellia sinensis (L.) O. Kuntze) to water-deficit stress // J. Horticultural Sci. Biotechnol. 2015 № 90(4). P. 395400. doi: 10.1080/14620316.2015.11513200. 0.4236/ajps.2012.34054. 
11.Waheed A., Hamid F.S., Shah A.H., Ahmad H., Khalid A., et al. Response of different tea (Camellia sinensis L.) clones against drought stress // J. Master Environ. Sci. 2012. №3. Pp. 395-410.

12. Мирошниченко О.С. Биогенез, физиологическая роль и свойства каталазы // Биополимеры и клетка. 1992. № 8(6). С. 3-25

13.Притула 3.В., Абильфазова Ю.С. Влияние биогенных микроэлементов на химический состав листа, основные физиологические процессы, продуктивность и качество плодов мандарина // Субтропическое и декоративное садоводство. 2004. № 39(2). C. $427-440$.

14. Gao X.Y., Yang G.P., Xu Z.Q. and Xu F.C. (1999) 'Effect of calcium on antioxidant enzymes of lipid peroxidation of Soy-bean leaves under water stress // Journal of South China Agricultural University. Vol. 2, pp. 58-62.

15. Shu M.Y. and Fan M.Q. (2000) Effect of osmotic stress and calcium on membrane-lipid peroxidation and the activity of defense enzymes in Fir Seedling // Forest Research. Vol. 4, pp. 391-396.

16. Ненько Н.И., Сергеева Н.Н., Караваева А.В. Исследование адаптивных реакций сортов яблони на фоне листовых обработок специальными удобрениями и регуляторами роста [Электронный ресурс] // Плодоводство и виноградарство Юга России. 2015. № 35(5). C. 83-94. URL: http://journalkubansad.ru/pdf/15/05/07.pdf. (дата обращения: 06.11.2019).

17. Белоус О.Г., Рындин А.В., Притула 3.В. Методические рекомендации по применению диагностических показателей устойчивости растений чая к стрессфакторам. Сочи, 2009. $21 \mathrm{c.}$

18. Филиппов Л.А. Рефрактометрический метод и принципы диагностирования сроков полива чайных растений // Водный режим и орошение плодовых и субтропических культур в горных условиях (тр. НИИГСиЦ). 1975. №21. С. 102-122.

19. Гунар И.И. Практикум по физиологии растений. М.: Колос, 1972. С.100-102.

20. Ли М., Ван Г., Лин Ц. Кальций способствует адаптации культивируемых клеток солодки к водному стрессу, индуцированному полиэтиленгликолем // Физиология растений. 2004. №51(4). С. 575-581.

21.Медведев С.С. Кальциевая сигнальная система растений // Физиология растений. 2005. № 52(2). С. 282-305.

22. Upadhyaya H., Panda S.K., Dutta B.K. CaCl2 improves post-drought recovery potential in Camellia sinensis (L) O. Kuntze // Plant Cell Rep. 2011 № 30. p. 495-450.

\section{References}

1. Bhagat R.M., Baruah R.D., Cacigue S. Climate and tea [Camellia sinensis (L.) O. Kuntze] production with special reference to northeastern India: a review // Journal of Environmental Research and Development. 2010. №4 (4). R. 1017-1028.

2. Baruah R.D., Bhagat R.M. Climate trends of Northeastern India: a longterm pragmatic analysis for tea production // Two and a Bud. 2012. № 59(2). R. 46-49.

3. Malyukova L.S. Ocenka vliyaniya meteorologicheskih uslovij na bioproduktivnost' pochv chajnyh plantacij v usloviyah Chernomorskogo poberezh'ya Rossii // Plodovodstvo i yagodovodstvo Rossii. 2014. №38 (1). S. 255-261.

4. Malyukova L.S., Kozlova N.V. Zonal'nye tipy pochv vlazhnyh subtropikov Chernomorskogo poberezh'ya Rossii. // Subtropicheskoe i dekorativnoe sadovodstvo: nauch. tr. / GNU VNIIC i SK Rossel'hozakademii. Vyp. 56. Sochi, 2016. S. 146-156.

5. Bush D.S. Calcium regulation in plant cells and its role in signaling. Annu. Rev. Plant Physiol. Plant Mol. Biol // 1995. № 46. R. 95-122. 
6. Bowler C., Fluhr B. The role of calcium and activated oxygen as signals for controlling cross-tolerance. Trend plant sci. // 2000.№ 5. R.241-243.

7. Yin D., Kuczera K., Squer T.C. The sensitivity of carboxyl-terminal methionines in calmodulin isoforms to oxidation by $\mathrm{H} 2 \mathrm{O} 2$ modulates the ability to activate the plasma membrane Ca- ATPase. Chem. Res.toxicol. // 2000.v.13. p. 103-110.

8. Upadhyaya H, Dutta B.K., Sahoo L., Panda S.K. Comparative effect of Ca, K, Mn and B on post-drought stress recovery in tea [Camellia sinensis (L.) O. Kuntze] // Amegican Journal Plant Science. 2012. №3. R. 443-460.

9. Pritula Z.V., Malyukova L.S. Vliyanie biogennyh elementov (Mg, Zn, B) na vodnyj rezhim chaya (Samellia Sinensis (L.) Kuntze) v usloviyah prodolzhitel'noj zasuhi i gipertermii // Problemy agrohimii i ekologii. 2017. № 3. S. 31-34.

10. Maritim T.K., Kamunya S.M., Mireji P., Wendia C.M., Muoki R.C., Cheruiyot E.K., Wachira F.N. Physiological and biochemical response of tea (Camellia sinensis (L.) O. Kuntze) to water-deficit stress // J. Horticultural Sci. Biotechnol. 2015 № 90(4). R. 395400. doi: 10.1080/14620316.2015.11513200. 0.4236/ajps.2012.34054.

11.Waheed A., Hamid F.S., Shah A.H., Ahmad H., Khalid A., et al. Response of different tea (Camellia sinensis L.) clones against drought stress // J. Master Environ. Sci. 2012. №3. Rr. 395-410.

12. Miroshnichenko O.S. Biogenez, fiziologicheskaya rol' i svojstva katalazy // Biopolimery i kletka. 1992. № 8(6). S. 3-25

13.Pritula Z.V., Abil'fazova Yu.S. Vliyanie biogennyh mikroelementov na himicheskij sostav lista, osnovnye fiziologicheskie processy, produktivnost' i kachestvo plodov mandarina // Subtropicheskoe i dekorativnoe sadovodstvo. 2004. № 39(2). S. 427-440.

14. Gao X.Y., Yang G.P., Xu Z.Q. and Xu F.C. (1999) 'Effect of calcium on antioxidant enzymes of lipid peroxidation of Soy-bean leaves under water stress // Journal of South China Agricultural University. Vol. 2, pp. 58-62.

15. Shu M.Y. and Fan M.Q. (2000) Effect of osmotic stress and calcium on membranelipid peroxidation and the activity of defense enzymes in Fir Seedling // Forest Research. Vol. 4, pp. 391-396.

16. Nen'ko N.I., Sergeeva N.N., Karavaeva A.V. Issledovanie adaptivnyh reakcij sortov yabloni na fone listovyh obrabotok special'nymi udobreniyami i regulyatorami rosta [Elektronnyj resurs] // Plodovodstvo i vinogradarstvo Yuga Rossii. 2015. № 35(5). S. 83-94. URL: http://journalkubansad.ru/pdf/15/05/07.pdf. (data obrashcheniya: 06.11.2019).

17. Belous O.G., Ryndin A.V., Pritula Z.V. Metodicheskie rekomendacii po primeneniyu diagnosticheskih pokazatelej ustojchivosti rastenij chaya $\mathrm{k}$ stress-faktoram. Sochi, 2009. $21 \mathrm{~s}$.

18. Filippov L.A. Refraktometricheskij metod i principy diagnostirovaniya srokov poliva chajnyh rastenij // Vodnyj rezhim i oroshenie plodovyh i subtropicheskih kul'tur v gornyh usloviyah (tr. NIIGSiC). 1975. №21. S. 102-122.

19. Gunar I.I. Praktikum po fiziologii rastenij. M.: Kolos, 1972. S.100-102.

20. Li M., Van G., Lin C. Kal'cij sposobstvuet adaptacii kul'tiviruemyh kletok solodki $\mathrm{k}$ vodnomu stressu, inducirovannomu polietilenglikolem // Fiziologiya rastenij. 2004. №51(4). S. 575-581.

21.Medvedev S.S. Kal'cievaya signal'naya sistema rastenij // Fiziologiya rastenij. 2005. № 52(2). S. 282-305.

22. Upadhyaya H., Panda S.K., Dutta B.K. CaCl2 improves post-drought recovery potential in Camellia sinensis (L) O. Kuntze // Plant Cell Rep. 2011 № 30. p. 495-450. 